\title{
A TUTELA INIBITÓRIA COMO INSTRUMENTO DE PROTEÇÃO DOS DIREITOS DA PERSONALIDADE
}

\section{THE INHIBITORY TUTELAGE AS PERSONALITY RIGHTS PROTECTION INSTRUMENT}

\author{
Ricardo Duarte Guimarães \\ Antonio Jose Souza Bastos ${ }^{2}$
}

\section{RESUMO}

Este artigo visa à análise da utilização da tutela inibitória como instrumento de proteção dos direitos da personalidade, identificando as nuances deste instituto processual. Elencar-se-ão, em foco, os preceitos consubstanciados na Constituição Federal, no Código Civil, no Código de Processo Civil de 1973 e os preceitos correspondentes no NCPC (Lei $n^{\circ}$ 13.105/2015), que abarcam o tema em pauta. Assim, a partir do estudo de casos concretos, da legislação, da jurisprudência pátria, da doutrina especializada, e de publicações em periódicos, será verificada a colisão entre direitos fundamentais, quais sejam, os direitos à imagem, à honra, à privacidade $\mathrm{e}$ à intimidade, a liberdade de expressão e os direitos de acesso à cultura e à informação, a fim de se constatar, com base no princípio da dignidade da pessoa humana, a legalidade e efetividade da tutela em comento para garantia e prevenção de direitos personalíssimos na contemporaneidade.

Palavras-chave: Tutela inibitória, Instrumento processual, Proteção, Direitos da personalidade, Direitos fundamentais

\begin{abstract}
This article aims to analyze the use of inhibitory tutelage as of personal rights protection instrument, identifying the main points of this procedural institute. Will be to list, in focus, the principles embodied in the Constitution, the Civil Code, the Civil Procedure Code of 1973 and the corresponding provisions in the NCPC (Law No. 13,105/2015), covering the topic at hand. So from the case studies, legislation, Homeland jurisprudence, the specialist doctrine and publications in journals, the collision between fundamental rights will be observed, namely, the rights to the image, honor, private life and intimacy, freedom of expression and the rights of access to culture and information in order to be seen, based on the principle of human dignity, legality and effectiveness of tutelage under discussion for assurance and prevention of personal rights in the contemporary world.
\end{abstract}

Keywords: Inhibitory tutelage, Procedural tool, Protection, Personality rights, Fundamental rights

\footnotetext{
${ }^{1}$ Mestrado em Direito pela Universidade Federal da Bahia - UFBA, Bahia, (Brasil). Professor pela Faculdade São Salvador - FSSAL, Bahia, (Brasil). E-mail: ricardoduarte.adv@ outlook.com

${ }^{2}$ Mestrando em Planejamento Ambiental pela Universidade Católica do Salvador - UCSAL, Bahia, (Brasil). Professor pela Faculdade São Salvador - FSS, Bahia, (Brasil). E-mail: antoniojsbastos@gmail.com
} 


\section{INTRODUÇÃO}

O desenvolvimento tecnológico do mundo contemporâneo e o advento da Internet facilitaram a propagação e concatenação de informações e imagens da vida dos indivíduos, principalmente nas redes sociais (Web 2.0), o que passou a exigir maior cuidado e reflexão sobre os direitos da personalidade (especialmente honra, imagem, privacidade e intimidade), tendo em vista o exercício da liberdade de expressão e dos direitos de acesso à cultura e à informação.

A Constituição Federal, no inciso $X$ do seu art. 5\%, dispõe que "são invioláveis a intimidade, a vida privada, a honra e a imagem das pessoas, assegurado o direito a indenização pelo dano material ou moral decorrente de sua violação". Esta garantia consolidou os direitos da personalidade como direitos fundamentais que decorrem do Princípio da Dignidade da Pessoa Humana.

Assim, necessitam tais direitos de uma tutela jurisdicional diferenciada, específica, que reconheça suas peculiaridades e conceda uma proteção eficaz, consoante preceitua o art. 12 do Código Civil ("Pode-se exigir que cesse a ameaça, ou a lesão, a direito da personalidade, e reclamar perdas e danos, sem prejuízo de outras sanções previstas em lei.”), em consonância com os artigos 20 e 21 do mesmo diploma legal.

Neste sentido, a tutela inibitória, objeto do presente estudo, enquadra-se no campo da tutela processual preventiva, visando oferecer uma proteção anterior à prática do ilícito, adequando-se, em princípio, às nuances de proteção dos direitos da personalidade na atualidade. É, portanto, uma tutela voltada para o futuro, para a prevenção de ilícitos, amplamente estudada, em âmbito nacional, pelo exímio doutrinador processualista Luiz Guilherme Marinoni.

Todavia, esse tipo de tutela é criticado por parte da doutrina e muitas vezes refutado pelo judiciário quando utilizado para impedir a publicação ou a veiculação de informações ou imagens por, supostamente, se tratar de "censura", violando, supostamente, direitos inerentes à coletividade, de interesse público, como a liberdade de expressão e os direitos de acesso à cultura e à informação. 
Desse modo, o objetivo geral deste trabalho é estabelecer os limites de utilização da tutela inibitória como meio de proteção dos direitos da personalidade, sem que isto se traduza em abuso de direito, elencando-se algumas situações exemplificativas em que a mesma pode (e deve) ser utilizada, servindo de parâmetro para outros tipos de situações análogas.

Será analisada, assim, a dicotomia entre os direitos fundamentais envolvidos na questão, bem como serão apontados, através da consulta em livros, periódicos e sites, diferentes entendimentos doutrinários que cercam o tema em baila, a jurisprudência pátria e a legislação atinente à matéria, em especial, o Código de Processo Civil (em correspondência com o NCPC), o Código Civil e a Constituição Federal.

Inicialmente, abordar-se-ão os aspectos conceituais e estruturais dos direitos fundamentais (essencialmente a diferença entre regras e princípios), bem como os seus limites no âmbito de colisão com outros direitos de mesma espécie. Em seguida, serão apresentados os direitos da personalidade em dicotomia com as liberdades fundamentais e os direitos de acesso à cultura e à informação.

Logo após, explanar-se-á sobre a tutela inibitória através do panorama do Processo Civil brasileiro para o efetivo enfrentamento da questão objeto deste estudo. E, em tópico específico, serão analisadas algumas situações que envolvem o estudo proposto, a partir do contexto social contemporâneo (marcado, principalmente, pela evolução da rede mundial de computadores), e a tutela jurisdicional preventiva dos direitos da personalidade no ordenamento brasileiro.

Por fim, será constatado que é possível, na atual conjuntura jurídica e social do país, a utilização do instrumento em baila para proteção dos direitos da personalidade, especialmente quando houver flagrante e iminente violação à imagem, à honra, à privacidade e à intimidade, tendo em vista, principalmente, a extensão dos danos que poderão ser causados na prática do ato supostamente ilícito e a (im)possibilidade de efetiva reparação. 


\section{AS NORMAS DE DIREITOS FUNDAMENTAIS}

Inicialmente, para se obter bom entendimento acerca do tema, é preciso ter clara noção sobre os aspectos jurídicos que compõem os direitos fundamentais, uma vez que tais tipos de direitos serão amplamente estudados ao longo do presente trabalho.

Indaga-se: quais são as normas do ordenamento jurídico que são caracterizadas como normas de direitos fundamentais?

A norma de direito fundamental se caracteriza pela forma como é positivada, ou seja, quando a Constituição estabelece expressamente em determinado capítulo quais são os “direitos fundamentais" e associada diretamente outras disposições a tais direitos 3.

São também consideradas como normas de direitos fundamentais as disposições que, em que pese não estejam associadas diretamente a dispositivo de direito fundamental, possuem caráter atributivo (indireto), isto é, são necessárias para a fundamentação na aplicação da norma expressa no texto constitucional quando esta, por exemplo, possui uma forma estrutural aberta (genérica). Todavia, este tipo de norma, para se realizar, efetivamente, como normal fundamental, deve ser classificada como válida no sentido de possuir correta argumentação (fundamentação) na sua correlação com os direitos diretamente expressos. ${ }^{4}$

As normas de direitos fundamentais se dividem em regras e princípios. Segundo Robert Alexy, "essa distinção é a base da teoria da fundamentação no âmbito dos direitos fundamentais e uma chave para a solução dos problemas centrais da dogmática dos direitos fundamentais". 5

Ao se basear na teoria de Alexy, Virgílio Afonso da Silva delineia a "teoria dos princípios", distinguindo regras e princípios da seguinte forma: pelas regras são garantidos direitos (impostos deveres) definitivos; já pelos princípios, são garantidos os direitos (impostos deveres) denominados de prima facie.

Tal entendimento se traduz no fato de que um direito consubstanciado em uma regra deve ser realizado totalmente, enquanto que um direito consubstanciado em um princípio possui, em termos gerais, realização parcial, pois há uma diferenciação entre o que é garantido prima facie e o que é garantido em definitivo. ${ }^{6}$ 
Neste sentido, os princípios são "mandamentos de otimização". Isso quer dizer que os princípios podem ser realizados em diferentes graus, uma vez que exigem que algo deve ser realizado em máxima medida possível, de acordo com possíveis condições fáticas e jurídicas para tanto, o que, em casos complexos, é difícil de ocorrer, uma vez que tal aspecto “máximo" acaba por esbarrar na proteção de outros princípios. Diferentemente, as regras jurídicas não dependem de condições fáticas/jurídicas para serem aplicadas. Nesta dicotomia, se estabelece que a norma é aplicada, no caso das regras, por subsunção, e no caso dos princípios, por sopesamento. ${ }^{7}$

Assim explica Alexy:

Da relevância de um princípio em um determinado caso não decorre que o resultado seja aquilo que o princípio exige para esse caso. Princípios representam razões que podem ser afastadas por razões antagônicas. A forma pela qual deve ser determinada a relação entre razão e contra-razão não é algo determinado pelo próprio princípio.

Os princípios, portanto, não dispõem da extensão de seu conteúdo em face dos princípios colidentes e das possibilidades fáticas. O caso das regras é totalmente diverso. Como as regras exigem que seja feito exatamente aquilo que elas ordenam, elas têm uma determinação da extensão de seu conteúdo no âmbito das possibilidades jurídicas e fáticas. Essa determinação pode falhar diante de impossibilidades jurídicas e fatias; mas, se isso não ocorrer, então vale definitivamente aquilo que a regra prescreve. ${ }^{8}$

O referido autor, criticando o modelo simplista de Dworkin - de que as regras válidas devem ser aplicadas na perspectiva "tudo-ou-nada", enquanto os princípios servem para nortear, sem refletir uma decisão direita - explicita que tais institutos se diferenciam, principalmente, no que tange aos conflitos e colisões. ${ }^{9}$

\footnotetext{
3 ALEXY, Robert. Teoria dos direitos fundamentais. 2. ed. Tradução de Virgílio Afonso da Silva. São Paulo: Malheiros, 2011. p. 68.

${ }^{4}$ ALEXY, 2011, p. 72-74.

${ }^{5}$ Ibid., p. 85.

6 SILVA, Virgílio Afonso da. O conteúdo essencial dos direitos fundamentais e a eficácia das normas constitucionais. Revista de Direito do Estado, São Paulo: Renovar, n. 4, 2006. p. 26-27.

${ }^{7}$ Ibid., p. 27-28.

${ }^{8}$ ALEXY, 2011, p. 104.

${ }^{9}$ ALEXY, loc. cit.
} 
Para Humberto Ávila, "no caso de colisão entre regras, uma delas deve ser considerada inválida. Os princípios, ao contrário, não determinam absolutamente a decisão, mas somente contêm fundamentos, os quais devem ser conjugados com outros fundamentos provenientes de outros princípios". ${ }^{10}$

Alexy pontua que um conflito entre regras é solucionado através de uma cláusula de exceção ou através da declaração de invalidade de uma delas. Já a colisão entre princípios (quando algo é permitido por um princípio e proibido por outro) é solucionada por cessão: um princípio, no caso concreto, irá, apenas, preponderar em relação ao outro, por possuir precedência sob determinadas condições. E conclui o teórico: “Conflitos entre regras ocorrem na dimensão da validade, enquanto as colisões entre princípios - visto que só princípios válidos podem colidir - ocorrem, para além dessa dimensão, na dimensão do peso."11

É nesta concepção de colisão entre princípios e de "peso" que se concebe a técnica da ponderação de interesses. Na lição de Ingo Wolfgang Sarlet, a "técnica da ponderação, tanto no âmbito do direito público quanto na seara do direito privado, [...] consolidou sua posição como instrumento apto a determinar a solução juridicamente correta em cada caso, com o destaque para solução dos conflitos entre direitos e princípios fundamentais". ${ }^{12}$

Desse modo, Mônica Aguiar afirma que "os direitos fundamentais são veiculados, normalmente, mediante princípios. Não se resolve o conflito afastando-se um em detrimento do outro, [...] senão sopesando-se os valores envolvidos, a fim de escolher qual deles, no caso concreto, prevalecerá. ${ }^{13}$ É nesta percepção que se insere a colisão entre a liberdade de expressão e os direitos da personalidade, ambos, direitos fundamentais, entre os quais, não há relação de hierarquia. ${ }^{14}$

${ }^{10}$ ÁVILA, Humberto. Teoria dos Princípios: da definição à aplicação dos princípios jurídicos. 14. ed. São Paulo: Malheiros, 2013. p. 40.

11 ALEXY, op. cit., p. 92-94. Aqui, no que se refere a "dimensão do peso", Alexy refere-se aos apontamentos de Ronald Dworkin.

${ }^{12}$ SARLET, Ingo Wolfgang. A eficácia dos direitos fundamentais: uma teoria geral dos direitos fundamentais na perspectiva constitucional. 11. ed. Porto Alegre: Livraria do Advogado, 2012. p. 410-411.

${ }^{13}$ AGUIAR, 2002, p. 116.

${ }^{14}$ GODOY, 2001, p. 66. 
Luís Roberto Barroso, ao analisar a moderna interpretação constitucional e fundamentar a necessidade de ponderação na colisão entre princípios, ensina:

A moderna interpretação constitucional diferencia-se da tradicional em razão de alguns fatores: a norma, como relato puramente abstrato, já não desfruta de primazia; o problema, a questão tópica a ser resolvida passa a fornecer elementos para sua solução; o papel do intérprete deixa de ser de pura aplicação da norma preexistente e passa a incluir uma parcela de criação do Direito do caso concreto. E, como técnica de raciocínio e de decisão, a ponderação passa a conviver com a subsunção. Para que se legitimem suas escolhas, o intérprete terá de servir-se dos elementos da teoria da argumentação, para convencer os destinatários do seu trabalho de que produziu a solução constitucionalmente adequada para a questão que lhe foi submetida. ${ }^{15}$

A ponderação é um processo que se constitui por três etapas: a identificação das normas pertinentes ao caso pelo intérprete, verificando os conflitos entre elas; a identificação das condições fáticas e as interações com as normas; a análise conjunta dos diferentes grupos de normas e as circunstâncias concretas, apurando os pesos a serem atribuídos aos elementos da questão em embate, estabelecendo o grupo de normas que irá preponderar. Após este processo, é preciso, ainda, se for o caso, optar pelo grau de intensidade com que o grupo de normas será aplicado, sendo que todo o procedimento deve ser pautado na proporcionalidade e na razoabilidade. ${ }^{16}$

Ou seja, haverá sempre um limite traçado não somente pelos princípios expressos na Constituição, mas, também, por princípios implícitos, norteadores da própria ordem jurídica pátria, como o princípio da proporcionalidade. ${ }^{17}$ Este princípio, perante o antagonismo entre direitos fundamentais, se torna instrumento de interpretação na busca de uma solução conciliatória, para a qual é extremamente adequado. ${ }^{18}$

\footnotetext{
${ }^{15}$ BARROSO, 2007, p. 101.

${ }^{16}$ Ibid., p. 107-108.

${ }^{17}$ AGUIAR, 2002, p. 117.

${ }^{18}$ BONAVIDES, Paulo. Curso de Direito Constitucional. 9. ed. São Paulo: Malheiros, 2000. p. 386. O autor explica que o princípio da proporcionalidade é comumente utilizado pelas cortes constitucionais europeias para dirimir a colisão entre direitos fundamentais. BONAVIDES, loc. cit.
} 
E essa relação de otimização dos princípios colidentes pela técnica da ponderação nada mais é que sopesamento, uma vez que serão avaliados o grau de não satisfação ou afetação de um dos princípios, a importância da satisfação do princípio colidente e se a importância desta satisfação justifica a afetação ou não satisfação do outro princípio. ${ }^{19}$

Gustavo Amaral observa que a liberdade de expressão é um "direito parcialmente independente", por não depender necessariamente da ação estatal, que comporta os "conflitos de delimitação", quando colide com outro direito fundamental como o direito à honra. Nesses casos será decidido, diante das circunstâncias concretas, por ponderação, qual direito prevalecerá. ${ }^{20}$

Luis Felipe Salomão exemplifica com a atividade da comunicação social: existindo a “colisão de direitos fundamentais, cabe ao juiz avaliar, sopesar, estabelecer quais os valores a preponderar, se a relevância da notícia e informação, ou os direitos à privacidade e intimidade". ${ }^{21}$

Dessa forma, se faz importante a análise desse tipo de colisão (entre princípios/direitos fundamentais) através do emblemático caso "Lebach", apresentado por Alexy. ${ }^{22}$

Na década de 1970, uma emissora de televisão, na Alemanha, exibiria um filme sobre um crime cometido por um condenado que estava na iminência de ser libertado da prisão. O condenado apresentou reclamação constitucional, uma vez que a medida cautelar que propôs para que o filme não fosse exibido, com base na ameaça sobre sua ressocialização, fora rejeitada pelo Tribunal Estadual e pelo Tribunal Superior Estadual. ${ }^{23}$

\footnotetext{
${ }^{19}$ ALEXY, 2011, p. 594.

${ }^{20}$ AMARAL, Gustavo. Direito, escassez e escolha: critérios jurídicos para lidar com a escassez de recursos e as decisões trágicas. 2. ed. Rio de Janeiro: Lumen Juris, 2010. p. 44-45. Aqui, Amaral apoia-se na lição de Gilmar Mendes.
}

${ }^{21}$ SALOMÃO, Luis Felipe. Direito Privado: teoria e prática. Rio de Janeiro: Forense, 2013. p. 292. E complementa o Ministro do STJ: "A ponderação de valores, entre o dever de noticiar - ensejando o direito da sociedade de estar bem informada -, e o resguardo ao direito à intimidade e ao sigilo. É o que a doutrina considera como o direito ao "segredo da desonra"'. Ibid., p. 293.

22 O caso "Lebach" é apresentado, também, por Barroso.

${ }^{23}$ ALEXY, 2011, p. 100. 
O Tribunal Constitucional Federal, por sua vez, dentro da concepção da "teoria das condições de precedência", desenvolveu o "sopesamento" para solução da colisão entre os princípios que abarcavam a causa, concebidos na Constituição alemã: proteção da personalidade do indivíduo e liberdade de informação. De forma isolada, um princípio permitiria a exibição do filme, enquanto o outro proibiria; todavia, como nenhum dos dois poderia ser invalidado, o Tribunal Constitucional decidiu, pela análise das circunstâncias do caso concreto, sobre qual interesse se sobressairia (ou cederia): o privado ou o público. ${ }^{24}$

Neste caso, a partir da aplicação da técnica da ponderação de interesses, ficou decretada a impossibilidade de exibição do filme, já que a repetição da veiculação do crime ocorrido não estaria mais pautado em um interesse público atual de informação e colocaria em risco a ressocialização do condenando que seria liberto. ${ }^{25}$

É em semelhante dicotomia que surge o debate acerca da colisão entre direitos fundamentais (liberdade de expressão e direitos da personalidade) no âmbito da utilização da Tutela Inibitória.

Em alguns casos, da mesma forma, ante a determinados critérios, tendo em vista a limitação dos direitos fundamentais, a ponderação de interesses deve ser adotada. Contudo, adenda Aguiar: a liberdade do julgador em ponderar "não pode importar em disputa com a primazia do legislador, sob pena de perder-se em segurança jurídica tudo o quanto se ganha em termos de justiça, ainda porque, admitir-se o inverso é permitir uma subversão das funções constitucionalmente alinhadas [...]”.

A ponderação, na colisão de direitos fundamentais, deve ser aplicada sob o crivo da proporcionalidade e razoabilidade, mas sem perder de vista a opção do legislador na proteção dos direitos envolvidos.

Analogamente, trazendo o exemplo do caso "Lebach" para a atualidade, no contexto do presente estudo, o filme seria facilmente publicado na Internet e, sem dúvida, o indivíduo teria o seu direito de ressocialização (ou direito ao esquecimento) violado.

\footnotetext{
${ }^{24}$ Ibid., p. 101.

${ }^{25}$ ALEXY, 2011,p. 102.
} 
Dessa forma, tendo conhecimento da iminente violação à proteção de sua personalidade, seria possível que o indivíduo recorresse à justiça através da tutela inibitória a fim de cessar esta ameaça?

É nesse tipo de questionamento que será pautado o desenvolvimento da análise acerca da utilização da tutela inibitória como meio de prevenção a violação dos direitos da personalidade em detrimento do exercício da liberdade de expressão e dos direitos de acesso à cultura e informação.

\section{A LIBERDADE E OS DIRETOS DE ACESSO À CULTURA E À INFORMAÇÃO}

José Afonso da Silva, ao definir o ser humano como ser liberto, aduz que este, na medida em que exerce maior domínio sobre a natureza e as relações sociais, se torna cada vez mais livre. O homem, no decorrer da história, se liberta em busca do conhecimento e, a partir do domínio das leis da natureza, passa a compreender as leis da necessidade, atuando, então, de forma transformadora, sobre o real/social. ${ }^{26}$

A evolução tecnológica e sua influência na vida (pós) moderna são a realidade do mundo contemporâneo. Não há como afastar os avanços oriundos do mundo globalizado. Em pleno século XXI, o direito não fica imune a essa influência. Consoante já exposto, são visíveis os efeitos da tecnologia no âmbito jurídico. O direito deve(ria) acompanhar as mudanças inerentes a este "novo mundo", já que o homem, exercendo ainda mais a sua liberdade, necessita adequar as "regras" vigentes para ideal convívio em sociedade.

Insta indispensável, portanto, apontar como mais um dos fundamentos basilares do presente estudo as definições estruturais dos direitos de liberdade.

Pablo Stolze e Rodolfo Pamplona colocam que a liberdade tem sido encarada sob inúmeras perspectivas, dentre elas, civil, religiosa, sexual e política, "com a enunciação de componentes próprios e distintos como a liberdade de locomoção, de trabalho, de exercício de atividade, de estipulação contratual, de comércio, de culto, de organização sindical, de imprensa" etc. ${ }^{27}$ Ao escopo do presente estudo, importa debruçar análise específica acerca das 
liberdades de informação, de imprensa e, principalmente, de expressão, pelo enfoque social, do interesse público ao acesso à cultura e à informação.

Tais direitos (de liberdade), em sua origem (francesa), foram constituídos sob o viés do liberalismo, dos direitos civis (afora os políticos), como liberdades individuais. Dependendo da posição jurídica do cidadão, as liberdades têm uma condição "negativa" (status negativus) de defesa perante a intervenção estatal e, por isso, fora estabelecido o nome "direitos de liberdade". Por outro lado, tais direitos possuem uma condição, também, "positiva" (status positvus), como prestações necessárias ao desenvolvimento da própria existência do indivíduo. ${ }^{28}$

Neste último sentido, a liberdade é classificada de duas formas: liberdade interna e externa. A primeira, denominada também de "liberdade subjetiva/psicológica/moral" ou "liberdade de indiferença", está ligada ao livre-arbítrio, ou seja, representa a manifestação da vontade interior, do ser, nas escolhas, no querer. A segunda, denominada também de "liberdade objetiva" ou "liberdade de fazer", é caracterizada pelas expressões, pelo o que é exteriorizado a partir de uma escolha, ou seja, representa, de certa forma, o "poder". ${ }^{29}$

Então, com base no aspecto externo da liberdade, constituem-se a liberdade de expressão e a liberdade de informação. A primeira traduz o juízo de valor, ou seja, a manifestação intelectual, o direito de externar ideias e opiniões. E a segunda é caracterizada pela objetividade, ou seja, pela simples comunicação de fatos, solidificando o direito (difuso) à informação e o direito (individual) de informar. ${ }^{30}$ Ambas estão intimamente ligadas à liberdade de imprensa, como se verá.

\footnotetext{
${ }^{26}$ SILVA, José Afonso da. Curso de Direito Constitucional Positivo. 30. ed. São Paulo: Malheiros Editores, 2008. p. 231.

${ }^{27}$ GAGLIANO; PAMPLONA FILHO, 2011, p. 209.

${ }^{28}$ CANOTILHO, J.J Gomes. Direito constitucional e teoria da constituição. 7. ed. Coimbra: Almedina, 2011. p. 395.

${ }^{29}$ SILVA, 2008, p. 231-232.

${ }^{30}$ BARROSO, 2007, p. 115. O autor esclarece que "a liberdade de informação se insere na liberdade de expressão em sentido amplo, mas a distinção parece útil por conta de um inegável interesse prático, relacionado com os diferentes requisitos exigíveis de cada uma das modalidades e suas limitações.” Ibid., p. 116. Cumpre ressaltar que, para o objetivo deste trabalho, importa, primordialmente, a liberdade de expressão (em sentido amplo) sob o enfoque do interesse público, da sua dimensão coletiva.
} 
Assim, a Constituição Federal de 1988, garantiu a proteção destes institutos no art. $5^{\circ}$, incisos IV ("é livre a manifestação do pensamento, sendo vedado o anonimato"), IX (“é livre a expressão da atividade intelectual, artística, científica e de comunicação, independentemente de censura ou licença"), XIV ("é assegurado a todos o acesso à informação e resguardado o sigilo da fonte, quando necessário ao exercício profissional”), e inciso XXXIII (“todos têm direito a receber dos órgãos públicos informações de seu interesse particular, ou de interesse coletivo ou geral, que serão prestadas no prazo da lei, sob pena de responsabilidade, ressalvadas aquelas cujo sigilo seja imprescindível à segurança da sociedade e do Estado”), sendo considerados, portanto, direitos fundamentais. E estas disposições consubstanciam, ainda, a garantia constitucional da cultura (artigos 215 a 216-A) e da comunicação social (artigos 220 a 224).

Porém, as liberdades não podem ser interpretadas de forma extrema. Não se pode olvidar que o exercício da liberdade de uma pessoa é limitado pela esfera jurídica de outra. É como diz o ditado "a liberdade de um termina onde começa a do outro". Existem limites aos direitos de liberdade. ${ }^{31}$

É diante deste panorama que se consolida a dicotomia entre as "liberdades" e os direitos da personalidade (interesse privado), na qual se insere o tema pauta.

\section{OS DIREITOS DA PERSONALIDADE}

Por outro lado, ao mesmo tempo em que a liberdade do homem ao longo do seu desenvolvimento se baseia principalmente na proteção de direitos inerentes a práticas externas, e em âmbito coletivo, os aspectos íntimos e pessoais dos indivíduos são, também, extremamente relevantes, necessitando, assim, os direitos inerentes à personalidade, proteção especial.

Consoante já exposto, a Constituição da República, no inciso X do seu art. $5^{\circ}$, prevê a inviolabilidade da intimidade, vida privada, honra e imagem dos indivíduos.

\footnotetext{
${ }^{31}$ GAGLIANO; PAMPLONA FILHO, 2011, p. 210.
} 
Esta garantia consolidou os direitos da personalidade como direitos fundamentais, sendo estes caracterizados pela doutrina como “inatos, intransmissíveis, inalienáveis, irrenunciáveis, imprescritíveis, impenhoráveis, extrapatrimoniais, vitalícios, necessários ou indispensáveis, oponíveis erga omnes, e relativamente disponíveis." ${ }^{32}$

Assim, os direitos da personalidade, então reconhecidos como direitos autônomos (de titularidade dos indivíduos), foram concebidos com base no Princípio da Dignidade da Pessoa Humana. ${ }^{33}$ A partir disso, é possível relativizar a indisponibilidade de tais direitos, analisando-os pela perspectiva da Autonomia Privada, que é conceituada pela civilista Roxana Borges da seguinte forma:

O conceito de autonomia privada, mais restrito, corresponde ao poder de realização de negócios jurídicos, ou seja, a liberdade negocial. Entende-se, em geral, autonomia privada como o poder atribuído pelo ordenamento jurídico ao indivíduo para que este possa reger, com efeitos jurídicos, suas próprias relações. Esse poder confere às pessoas a possibilidade de regular, por si mesmas, as próprias ações e suas consequências jurídicas, ou de determinar o conteúdo e os efeitos de suas relações jurídicas, tendo o reconhecimento e podendo contar com a proteção do ordenamento jurídico. 34

Ou seja, existe a possibilidade de disponibilidade dos direitos da personalidade, desde que sejam obedecidos os limites constantes na autorização concedida pelo titular do direito, através de uma cessão, licença ou permissão. Assim, o negócio jurídico realizado entre as partes para utilização de direitos da personalidade deve ser minuciosamente detalhado, a permissão deve ser expressa e as disposições interpretadas restritivamente. ${ }^{35}$

É neste contexto que a Lei Federal no 10.406, de 10 de janeiro de 2002 (Código Civil) dispõe em seus arts. 20 e 21 a tutela de alguns dos direitos da personalidade:

\footnotetext{
${ }^{32}$ CASTRO, Mônica N. A. da S. Honra, imagem, vida privada e intimidade, em colisão com outros direitos. Rio de Janeiro: Renovar, 2002, p. 67.

${ }^{33}$ BARROSO, Luís Roberto. Op. Cit, p. 109.

${ }^{34}$ BORGES, Roxana Cardoso Brasileiro. Direitos de Personalidade e Autonomia Privada. 2. ed. São Paulo: Saraiva, 2007, p. 47.

${ }^{35}$ Ibidem, p. 121-122.
} 
Art. 20. Salvo se autorizadas, ou se necessárias à administração da justiça ou à manutenção da ordem pública, a divulgação de escritos, a transmissão da palavra, ou a publicação, a exposição ou a utilização da imagem de uma pessoa poderão ser proibidas, a seu requerimento e sem prejuízo da indenização que couber, se lhe atingirem a honra, a boa fama ou a respeitabilidade, ou se destinarem a fins comerciais.

Art. 21. A vida privada da pessoa natural é inviolável, e o juiz, a requerimento do interessado, adotará as providências necessárias para impedir ou fazer cessar ato contrário a esta norma.

Apesar do art. 20 suscitar possível disponibilidade, percebe-se, via de regra, a vedação à divulgação de escritos ou utilização de imagem de alguém tendo por fim o lucro, ou que acarretem violação à honra, boa fama ou respeitabilidade do indivíduo. O artigo 21, por sua vez, não dá margem a qualquer disponibilidade, traçando a inviolabilidade da vida privada.

Na lição do jurista italiano Adriano De Cupis, a honra é a dignidade da pessoa que se reflete no seu próprio sentimento e na concepção das outras pessoas. ${ }^{36}$ E na lição de Pontes de Miranda, a honra é direito inato e universal do ser humano, que abrange o sentimento e a consciência de dignidade própria e a estima na consideração moral dos outros. ${ }^{37}$

Percebem-se, logo, duas "vias" desse direito: objetiva e subjetiva. O reconhecimento do direito à honra se caracteriza pela proteção da honra objetiva: reputação da pessoa, que compreende o bom nome e a fama perante a coletividade (no ambiente familiar, profissional, comercial etc.); e da honra subjetiva: sentimento pessoal de estima, ou a consciência da própria dignidade. ${ }^{38}$

Já em relação ao direito à imagem, a CF de 1988, além de proteger a inviolabilidade da imagem das pessoas no inciso X do seu art. $5^{\circ}$, assegurou, no inciso XXVIII, $a$, e no inciso $\mathrm{V}$, do mesmo artigo "a proteção às participações individuais em obras coletivas e à reprodução da imagem e voz humanas, inclusive nas atividades desportivas" e o "direito de resposta, proporcional ao agravo, além da indenização por dano material, moral ou à imagem”, respectivamente.

\footnotetext{
${ }^{36}$ DE CUPIS, Adriano. Os direitos da personalidade. Tradução de Adriano Vera Jardim e Antonio Miguel Caeiro. Lisboa: Livraria Morais, 1961. p. 111-112.

${ }^{37}$ PONTES DE MIRANDA. Tratado de direito privado - Parte Especial. Rio de Janeiro: Borsoi, 1971. p. 44.

${ }^{38}$ BITTAR, 1999, p. 129.
} 
Assim, o "direito à própria imagem"39, como direito fundamental, se refere aos aspectos da individualidade, identidade e reconhecimento da pessoa, como elo da realidade jurídica da imagem humana, posto que este direito somente existe se a representação visível de um indivíduo pode ser atribuída a um sujeito concreto. Neste certame, Aguiar faz a seguinte observação:

\begin{abstract}
A imagem, aqui, deve ser entendida não somente como a representação de uma pessoa, mas, também, como a forma pela qual ela é vista pela coletividade. Compreende-se nesse conceito, não apenas o semblante do indivíduo, mas partes distintas do seu corpo, sua própria voz, enfim, quaisquer sinais pessoais de natureza física pelos quais possa ser ela reconhecida. ${ }^{40}$
\end{abstract}

Antônio Chaves completa: "No sentido comum, é a representação pela pintura, escultura, fotografia, filme etc., [...] da pessoa humana. [...] Muito embora podemos considerar como imagem a reprodução de um pé, um braço, uma mão, um busto, não somente, pois, da pessoa humana inteira". ${ }^{41}$

E no que tange a privacidade e a intimidade, segundo Silmara Chinellato, tais institutos não possuem o mesmo significado: “Aquela tem âmbito maior, que contém a intimidade, ou seja, vida privada e intimidade podem ser consideradas círculos concêntricos. [...] Quem está autorizado a ter acesso à vida privada de alguém não está, automaticamente, autorizado a tê-lo quanto à intimidade do mesmo titular". ${ }^{42}$

Para Stolze e Pamplona, "a vida privada é entendida como a vida particular da pessoa natural (right of privacy)". ${ }^{43}$ E Mônica Aguiar define que o direito à vida privada é "o direito que tem cada indivíduo de excluir do conhecimento público fatos que denotem preferências e outros dados que a pessoa julgue devam ser subtraídos dessa esfera de informação". ${ }^{44}$

\footnotetext{
${ }^{39}$ Termo adotado por Mônica Aguiar e Antônio Chaves.

${ }^{40}$ AGUIAR, 2002, p. 17.

${ }^{41}$ CHAVES, Antônio. Direito à própria imagem. Revista de informação legislativa, Brasília, v. 9, n. 34, p. 23-42, abr./jun. 1972. p. 23-24.

${ }^{42}$ CHINELLATO, 2014, p. 54.

${ }^{43}$ GAGLIANO; PAMPLONA FILHO, 2011, p. 214, grifos do autor.

${ }^{44}$ AGUIAR, op. cit., 2002, p. 31.
} 
E são diversos os bens jurídicos protegidos pelo direito à intimidade, mas todos têm como essência, em suma, fatos ou informações que possuem um caráter de exclusividade, de conhecimento, unicamente, da própria pessoa, que ocorrem em âmbito particular ou que são produzidas unilateralmente e que são (ou não) compartilhadas apenas com as pessoas que convivem intimamente com ela (geralmente os familiares mais próximos e amigos íntimos) e, às vezes, com alguns tipos de profissionais, específicos, como médico, psicólogo e advogado.

A Constituição Federal, ao incluir em seu texto a proteção ao direito à intimidade e à vida privada como institutos distintos, manteve corretamente as distinções doutrinárias entre a proteção da intimidade e a proteção da vida privada, já que são dois conceitos diversos, com extensões de tutela diferentes, que permitem a mais ampla proteção da pessoa humana, perante qualquer espécie de ofensa. ${ }^{45}$

Ademais, fundamental para o enfretamento do problema consubstanciado nesta pesquisa juntamente com a análise da Tutela Inibitória, o art. 12 da lei cível prevê a possibilidade de se cessar ameaça de lesão a direito da personalidade.

\section{A TUTELA INIBITÓRIA}

Pois bem. Para se verificar a possibilidade de utilização da tutela inibitória como instrumento de proteção dos direitos da personalidade, faz-se necessária a busca da conceituação e análise de seus elementos, fundamentos, pressupostos e principais nuances.

$\mathrm{O}$ ordenamento jurídico pátrio classifica as tutelas que podem ser provisionadas (tutelas cautelares, ressarcitórias, antecipatórias etc.) de acordo com a necessidade específica de cada caso concreto.

A tutela em comento se enquadra no campo da tutela preventiva, que visa à proteção da prática futura, repetição ou continuação do ilícito, preocupando-se com a integridade do direito e não em "consertar erros" (passados), o que lhe distingue das demais.

${ }^{45}$ SZANIAWSKI, 1993, p. 133. 
Defendida e difundida no Brasil principalmente por Luiz Guilherme Marinoni, tratase de ação autônoma, que independe de outro procedimento (principal). Diz-se, dessa forma, que a tutela inibitória, instrumentalmente, não possui relação com nenhum outro tipo de tutela.

Trata-se a tutela inibitória de espécie de tutela jurisdicional voltada para o futuro, que tem por escopo impedir a prática, a repetição e a continuação do ilícito. ${ }^{46}$

Paulo Ricardo Pozzolo, tanto, define "a tutela inibitória como aquela que tem em vista à prevenção da prática, da repetição ou da continuação de uma conduta antijurídica, ilícita ou danosa, que pode ser positiva ou negativa, contratual ou extracontratual”47

Trata-se de tutela específica que é viabilizada pelas técnicas processuais constantes no art. 461 do Código de Processo Civil (Lei $n^{\circ} 5.869 / 1973$ ), ${ }^{48}$ que se destina a impedir a prática de ato contrário ao direito, ou a sua repetição ou continuação, isto é, visa impedir a violação futura de um direito, ou que se dê continuidade a mesma quando já consumada. ${ }^{49}$

Neste sentido, o Novo Código de Processo Civil - NCPC (Lei no 13.105/2015), no seu art. 497, mantém sua referência à tutela em comento, sem qualquer alteração substancial.

Art. 497. Na ação que tenha por objeto a prestação de fazer ou de não fazer, o juiz, se procedente o pedido, concederá a tutela específica ou determinará providências que assegurem a obtenção de tutela pelo resultado prático equivalente.

Parágrafo único. Para a concessão da tutela específica destinada a inibir a prática, a reiteração ou a continuação de um ilícito, ou a sua remoção, é irrelevante a demonstração da ocorrência de dano ou da existência de culpa ou dolo.

\footnotetext{
${ }^{46}$ MARINONI, Luiz Guilherme. Tutela inibitória. Revista Consulex, Brasília, n. 41, p. 40-43, maio 2000, p. 41.

${ }^{47}$ POZZOLO, Paulo Ricardo. Ação inibitória do trabalho, p. 36.

48 “Art. 461. Na ação que tenha por objeto o cumprimento de obrigação de fazer ou não fazer, o juiz concederá a tutela específica da obrigação ou, se procedente o pedido, determinará providências que assegurem o resultado prático equivalente ao do adimplemento.”

${ }^{49}$ MARINONI, Luiz Guilherme; ARENHART, Sérgio Cruz. Curso de Processo Civil. São Paulo: Revista dos Tribunais, 2008. v. 4. p. 70-77. Os autores pontuam que o art. 84 do Código de Defesa do Consumidor também dispõe sobre a tutela específica.
} 
No entanto, não podemos deixar de observar e fazer referência a obrigação de não fazer, ao qual o dispositivo em comento trás, no seu capítulo XIII, seção IV, incluindo a referida tutela na execução do julgamento das ações relativas a prestação de fazer, não fazer e de entregar coisa.

A obrigação de não fazer, ou negativa, impõe a parte um dever de abstenção: o de não praticar o ato que poderia livremente fazer, se não se houvesse obrigado, ou por qualquer determinação neste sentido. ${ }^{50}$

A tutela inibitória busca a recomposição específica do direito, caracterizada na imposição de obrigação ao ofensor para prática de atos (ou a "não prática") que possibilitem o alcance do direito em iminente violação, inibindo, assim, o ilícito, impedindo seus efeitos concretos, a partir de uma "reparação" específica, e não o ressarcimento pecuniário.

Verifica-se a importância da tutela inibitória pelo fato de ser uma tutela que tem capacidade de inibir ou cessar a (ameaça de) lesão. Tamanha eficácia e força coativa causam reservas por parte da doutrina, como ainda se verá, uma vez que o deferimento da tutela em baila, ao mesmo tempo em que leva à satisfação do direito de determinado indivíduo, pode, por consequência, levar à restrição de direito de outrem.

Marinoni explica que, mesmo sendo dirigida a impedir a continuação de um ilícito, ainda assim a tutela inibitória não perde o seu caráter preventivo:

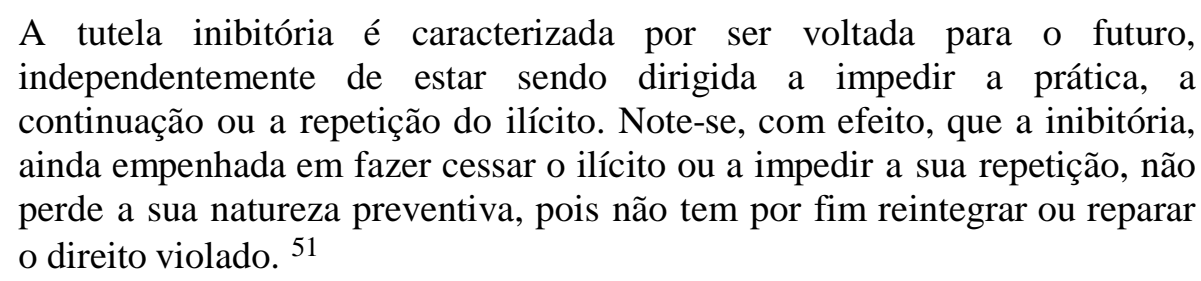

E o fato de a tutela inibitória não ter por objeto a reparação ou reintegração do direito violado não quer dizer que a pessoa lesada não disponha de outros métodos para requerê-las. A tutela inibitória pode ser cumulada com outras ações para promover a mais ampla tutela de direitos, consoante já fora reconhecido pelo STJ. ${ }^{52}$

\footnotetext{
${ }^{50}$ Washington de Barros Monteiro, Curso de direito civil, 29. ed., v. 4, p.102; silvio rodrigues, direito civil. v. 2 , p.41.

${ }^{51}$ MARINONI, Luiz Guilherme. Tutela Inibitória individual e coletiva. 4. ed. São Paulo: Revista dos Tribunais, 2006. p. 38-39.
} 
$\mathrm{O}$ art. $5^{\circ}$, inciso XXXV da CF impõe que "a lei não excluirá da apreciação do Poder Judiciário lesão ou ameaça a direito". Ou seja, a Carta Maior garante, através do princípio do acesso à justiça, a tutela efetivamente capaz de impedir a possível violação de um direito. A tutela inibitória, preventiva, portanto, tem por fundamento o direito à efetividade da tutela jurisdicional prevista na norma constitucional elencada.

Neste diapasão, Marinoni leciona que "há direito fundamental à efetividade da tutela jurisdicional e, assim, direito fundamental à tutela preventiva, o qual incide sobre o legislador - obrigando-o a instituir técnicas processuais capazes de permitir a tutela preventiva", além de incidir sobre os juízes que devem interpretar as normas processuais de modo a retirar delas instrumentos que viabilizem a concessão de uma tutela preventiva. ${ }^{53}$

A disposição do direito fundamental mencionado demonstra a possibilidade da tutela inibitória ser adotada para impedir a utilização ilegal de bem jurídico mediante simples reparação posterior de danos patrimoniais, já que na sociedade contemporânea os danos não se resumem à pecúnia (perdas e danos), ou seja, não dizem respeito apenas à esfera econômica do indivíduo; existem, também, os danos morais (extrapatrimoniais), relativos aos direitos da personalidade, como já visto, que ultrapassam a lógica do mero ressarcimento, uma vez que é irreparável, em sua integralidade, a violação a esses direitos.

Permitir que um ilícito se concretize sobre a esfera jurídica extrapatrimonial de determinado indivíduo, admitindo que tal violação seja reparada apenas com pagamento, é negar o advento do princípio da dignidade da pessoa humana. Isto é incompatível com toda a lógica pregada pelo ordenamento jurídico brasileiro, principalmente no que concerne aos direitos da personalidade.

\footnotetext{
${ }^{52}$ BRASIL. Superior Tribunal de Justiça. Recurso Especial no 681007/DF, rel. Min. Nancy Andrighi, j. 2.5.2006. Disponível em: <http://stj.jusbrasil.com.br/jurisprudencia/46668/recurso-especial-resp-681007-df-20040111274-6>. Acesso em: 17 out. 2014.

${ }^{53}$ MARINONI, Luiz Guilherme. Técnica processual e tutela dos direitos. São Paulo: Revista dos Tribunais, 2004. p. 254.
} 
Neste sentido, o uso da tutela inibitória na proteção dos direitos da personalidade é essencial para a garantia integral desses direitos. Para Marinoni, é clara a necessidade de se admitir a tutela preventiva, "do contrário, as normas que proclamam direitos, ou objetivam proteger bens fundamentais, não teriam qualquer significação prática, pois poderiam ser violados a qualquer momento, restando somente o ressarcimento do dano."

Dessa forma, a especificidade dos direitos da personalidade, de cunho essencialmente moral, justifica a utilização da tutela inibitória, que deve ser adequada aos casos concretos para que as normas constitucionais (e infraconstitucionais) sejam efetivadas, permitindo a correta proteção dos bens tutelados pelo ordenamento.

Importante frisar que o pressuposto da tutela inibitória, qual seja, a ameaça do ilícito, não se atém à noção de "probabilidade de dano"; relaciona-se, em verdade, ao ato ilícito propriamente dito ou à sua simples probabilidade de ser praticado, bastando apenas que seja provável a ocorrência de ilícito contrário ao direito para se configurar o pressuposto da tutela (preventiva). Esta distinção com o dano impede o engessamento da inibitória, pois, admitir que a tutela inibitória se destine apenas a inibir o dano, implica supor que não existe nada antes da sua ocorrência que possa ser caracterizado como ilícito civil. ${ }^{55}$

\section{Marinoni exemplifica:}

Assim, por exemplo, se há um direito que exclui um fazer, ou uma norma definindo que algo não pode ser feito, a mera probabilidade de ato contrário ao direito - e não o dano - é suficiente para a tutela jurisdicional inibitória. Ou seja, o titular de uma marca comercial tem o direito de inibir alguém de usar a sua marca, pouco importando se tal uso vai produzir dano. Do mesmo modo, se uma norma impede a venda de determinado produto, a associação dos consumidores (por exemplo) pode pedir a inibição da venda, sem se preocupar com dano. ${ }^{56}$

Existem casos em que há coincidência entre o dano e o ato contrário ao direito, devendo o autor, neste caso, fazer menção ao dano não como fundamento da tutela inibitória, mas sim como forma de consubstanciar o convencimento do magistrado.

\footnotetext{
${ }^{54}$ MARINONI, 2004, p. 253.

${ }^{55}$ MARINONI, 2004, p. 255.

${ }^{56}$ Ibid., p. 255-256.
} 
Para que seja deferida a tutela inibitória, basta que o autor demonstre a existência da ameaça de lesão.

Restando configurada apenas a lesão, ficando comprovado que não há mais ameaça (ou continuidade do ato lesivo), o titular do direito deverá, aí sim, se valer da tutela repressiva, através da indenização por perdas e danos, conforme preceitua o $\S 1^{\circ}$, do art. 461 do CPC, ${ }^{57}$ ou de outra forma de tutela específica para compensação do direito lesado, não mais da tutela inibitória, já que não existirá mais o que se inibir.

As indenizações proporcionadas pela tutela ressarcitória são adequadas aos direitos de natureza patrimonial, ou seja, àqueles que são suscetíveis de avaliação pecuniária. Todavia, quando se está diante de direitos da personalidade, a sua eficácia é bastante reduzida, uma vez que não garantem o bem de per si, mas sim a consolação do lesado e a punição do agente, dotando-se, pois, de um caráter punitivo-pedagógico. ${ }^{58}$

Em suma, a tutela inibitória é uma ação de conhecimento de natureza preventiva e mandamental (obriga a fazer ou não fazer). Por meio dela, o autor pode requerer, em juízo, o provimento para impedir a prática do ilícito, ou seja, a ameaça de lesão (ainda que nenhum ilícito anterior tenha sido produzido) ou inibir a repetição ou continuação do mesmo, tendo por fundamento o art. 461 do CPC de 1973 e o art. 497 do NCPC.

\section{A TUTELA PREVENTIVA DOS DIREITOS DA PERSONALIDADE}

\subsection{COLISÃO ENTRE DIREITOS FUNDAMENTAIS: A INTERNET E O CONTEXTO CONTEMPORÂNEO}

O advento da Internet é, sem dúvida, o grande marco do desenvolvimento tecnológico da sociedade contemporânea, e contribuiu de forma significativa para a propagação do exercício da liberdade de expressão e garantia dos direitos de acesso à cultura e à informação. Por outro lado, a disseminação de arquivos pessoais e os mais diversos tipos de informações na rede passou a contribuir, também, com o aumento da violação aos direitos da personalidade dos indivíduos, a exemplo dos crimes contra a honra. 
A Internet, também conhecida como rede mundial de computadores, é um meio de comunicação que interliga, em âmbito internacional, bilhões de usuários, permitindo a transmissão de informações de qualquer natureza, constituindo um verdadeiro sistema global de interatividade virtual.

Atualmente, a Internet faz parte do cotidiano dos indivíduos, mas sua expansão na sociedade brasileira ocorreu a partir do ano de 1995, quando se tornou comercialmente viável. ${ }^{59} \mathrm{Em}$ 1998, no auge do barateamento das comunicações do século XX, o número de usuários no Brasil passou de 140 milhões para 800 milhões nos anos subsequentes, chegando a 41,565 milhões no início de $2008 .{ }^{60}$

A transformação da Internet em instrumento de comunicação de massa foi possível graças à rede mundial World Wide Web (WWW ou Web). Esta ferramenta virtual permitiu uma evidência ímpar de textos, imagens e sons, relacionando-os com outros documentos, apenas com um simples clique, sem qualquer necessidade de se visualizar incontáveis protocolos de acesso. ${ }^{61}$

Pois bem. A revolução comunicacional promovida pela Web perpassa pelo desenvolvimento tecnológico do mundo moderno. A união dos "3Cs" (computação, comunicação e conteúdo) constituiu a contemporânea Sociedade Digital (ou Sociedade da Informação) na qual os conteúdos se tornaram bens jurídicos a serem tutelados pelo Direito. Assim, muitas questões e discussões surgiram a respeito dos conteúdos publicados na Internet que são extremamente necessários para que seja mantido o interesse na utilização do próprio meio de comunicação e da tecnologia em si. ${ }^{62}$

Neste diapasão, observa a especialista em Direito Digital, Patrícia Peck:

\footnotetext{
57 “Art. 461. [...] $§ 1^{\circ}$ A obrigação somente se converterá em perdas e danos se o autor o requerer ou se impossível a tutela específica ou a obtenção do resultado prático correspondente."

${ }^{58}$ LORENZETTI, Ricardo Luis. La tutela civil inhibitoria. Buenos Ayres: La Ley, 1995, p. 1218.

${ }^{59}$ BINICHESKI, Paulo Roberto. Responsabilidade Civil dos Provedores de Internet. Curitiba: Juruá, 2011, p. 199.

${ }^{60}$ PAESANI, Liliana Minardi. Direito e Internet. $6^{\mathrm{a}}$ ed. São Paulo: Atlas, 2013, p. 11.

${ }^{61}$ Ibidem, p. 12.

${ }^{62}$ PINHEIRO, Patrícia Peck. Direito Digital. $4^{\text {a }}$ ed. São Paulo: Saraiva, 2013, p. 159 - 160.
} 
No mundo virtual, o conteúdo tornou-se um objeto de negociação, um produto. A todo momento surge um novo site ou portal vendendo conteúdo como uma palavra mágica, um diferencial em relação à concorrência (só que a concorrência também vende conteúdo como um diferencial). O conteúdo na Internet não é gerado necessariamente para um comprador, mas torna-se cada vez mais uma mercadoria cuja posse agrega valor ao seu proprietário. [...] Assim como nas emissoras de radiodifusão, o conteúdo é que motiva a audiência. No mundo da convergência, uma audiência motivada torna-se também um potencial público consumidor. É prática comum, na maioria dos sites e portais, unir conteúdo e comercialização de produtos em uma mesma página. O conteúdo ganha então sua função econômica. ${ }^{63}$

A questão que se propõe análise no presente estudo está consubstanciada, principalmente, nos conteúdos publicados na rede mundial de computadores que, muitas vezes, são ilícitos e geram danos irreparáveis para os indivíduos.

Os Provedores de Aplicações da Internet, ou provedores de serviços e conteúdos, são responsáveis pela disponibilização de conteúdos na Web.

Assim ensina o exímio doutrinador Marcel Leonardi:

O provedor de conteúdo, finalmente, é toda pessoa natural ou jurídica que disponibiliza na Internet as informações criadas ou desenvolvidas pelos provedores de informação, utilizando servidores próprios ou os serviços de um provedor de hospedagem para armazená-las. [...] O provedor de conteúdo, na maior parte dos casos, exerce controle editorial prévio sobre as informações que divulga, escolhendo o teor do que será apresentado aos usuários antes de permitir o acesso ou disponibilizar as informações. ${ }^{64}$

Desse modo, é possível aferir que os Provedores de Aplicações da Internet são "culpados" pelo desenvolvimento da Web 2.0, que representa uma nova forma de se "encarar" a Web.

A Web 2.0 caracteriza uma mudança na participação dos usuários e dos desenvolvedores na Internet, principalmente a partir das Redes Sociais. A Web, nos últimos anos, passou a fazer parte do dia-a-dia das pessoas. A tecnologia da informação possibilitou uma espécie de "acessibilidade total", sem fronteiras, pela qual as pessoas passaram, também, a produzir novos bens e serviços variáveis através do mundo virtual.

\footnotetext{
${ }^{63}$ Ibidem, p. 160.

${ }^{64}$ LEONARDI, Marcel. Internet: Elementos Fundamentais. In: Responsabilidade Civil na Internet e nos demais Meios de Comunicação. Manoel J. Pereira dos Santos e Regina Beatriz Tavares da Silva, coordenadores. São Paulo: Saraiva, 2007, p. 60.
} 
Neste sentido, expões Patrícia Peck:

Conteúdo é a palavra chave da Internet. [...] A Web 2.0 é um movimento que indica uma tendência pela quebra de alguns paradigmas, derivado da observação de características comuns aos serviços que se estão consolidados como os mais importantes da Internet. [...] A Internet deixou de ser apenas uma rede de computadores e se consolidou como uma rede de pessoas; pessoas que participam cada vez mais, que querem se expor, seja por meio da divulgação de textos, comentários em blogs, compartilhamento de links ou apenas pela publicação das fotos de seu último aniversário. ${ }^{65}$

$\mathrm{Na}$ Web 2.0, os usuários são também produtores de conteúdo (provedores de informação) e, ao mesmo tempo, divulgam produções de terceiros e agregam novas informações a conteúdos já publicados (ou os modificam).

Todavia, o uso de colaboração em massa na Internet exige cuidados e, consequentemente, tutela jurídica específica. Não à toa, entrou em vigor, neste ano de 2014, o Marco Civil da Internet (Lei $n^{\mathbf{0}} 12.965 / 14$ ). "Quando o próprio internauta gera, manuseia, edita o conteúdo, tem que se ter todo o cuidado para que isso não promova a prática de ofensas digitais, em que os crimes contra a honra são os mais comuns (difamação, calúnia e injuria), bem como o uso não autorizado de imagem de pessoas". ${ }^{66}$

Dessa forma, uma das principais questões que envolvem o Direito na atualidade está consubstanciada na dicotomia (colisão) entre direitos fundamentais, quais sejam, os direitos da personalidade e a liberdade de expressão e os direitos de acesso à cultura e à informação, especialmente no âmbito da Internet.

Inúmeros são os casos de difamação, calúnia e injúria na rede mundial de computadores, além da utilização indevida (desautorizada) de imagem e violação à intimidade e privacidade das pessoas. Tais ilicitudes se agravam na "rede", pois são perpetuadas com extrema velocidade, sendo praticamente impossível constatar os seus alcances e, consequentemente, removê-las por completo, para impedir o acesso pelos usuários.

A título de exemplo, a atriz Carolina Dieckmann, em famosos casos nacionais, por duas vezes teve de recorrer à justiça em busca de indenização pela violação aos direitos da personalidade que lhes são inerentes, inclusive no âmbito da Internet, pela divulgação de imagens que violavam sua intimidade. 
No primeiro exemplo, em 2005, a atriz teve sua privacidade violada por humoristas do programa televisivo "Pânico" que passaram a perseguir e gravar/exibir imagens da atriz e de seu filho quando estava em sua residência. Além da exibição na TV, as imagens foram amplamente divulgadas na Internet. Em contrapartida, o "Pânico" alegou que o pleito se trava de censura, todavia, a atriz venceu a demanda e a Justiça do Rio de Janeiro condenou o programa a indenizá-la. ${ }^{67}$

Já no segundo exemplo, ocorrido em 2011, ao colocar seu laptop no conserto, Carolina Dieckmann foi chantageada para que suas fotos íntimas (salvas no aparelho) não fossem divulgadas na Internet. ${ }^{68} \mathrm{~A}$ atriz teve suas imagens disseminadas na "rede", o que culminou em comoção pública para criação de lei específica sobre este tipo de delito. E em 2012 foi sancionada a "Lei Carolina Dieckmann" (Lei n 12.737/12), sobre a tipificação criminal de delitos informáticos. ${ }^{69}$

Ademais, em um cenário ainda mais atual, são constantemente noticiados casos de violação à intimidade e imagem dos indivíduos na utilização de aplicativos de celulares, principalmente do "WhatsApp". Em recente decisão, com base no Marco Civil da Internet, a justiça de São Paulo exigiu que a sociedade empresária responsável pelo referido aplicativo identificasse os indivíduos que divulgaram o conteúdo de conversas em que foram compartilhadas fotomontagens pornográficas de uma estudante universitária. Infelizmente, hoje, diversos jovens sofrem com este tipo de exposição e acabam adquirindo doenças como depressão e, em alguns casos, até se suicidam. ${ }^{70}$

Portanto, o que se vê na atual sociedade contemporânea é uma verdadeira gama de ilícitos que acabam decorrendo do exercício de direitos como a liberdade de expressão e o acesso à cultura e à informação, em detrimento da proteção dos direitos da personalidade.

\footnotetext{
${ }^{65}$ Ibidem, p. $366-367$.

${ }^{66}$ PINHEIRO, Patrícia Peck. Op. Cit, p. 368.

${ }^{67}$ Disponível em: <http://www1.folha.uol.com.br/folha/ilustrada/ult90u62906.shtml> Acesso em 15 de Out. de 2014.

68 Disponível em: <http://direito.folha.uol.com.br/blog/as-fotos-de-carolina-dieckmann-nua-para-entender-oscrimes-do-caso> Acesso em 15 de Out. de 2014.

${ }^{69}$ Disponível em: <www1.folha.uol.com.br/fsp/cotidiano/81816-dilma-aprova-duas-leis-para-punir-crimesciberneticos.shtml> Acesso em 17 de out. de 2014.
} 
Conforme já fora analisado no presente trabalho, é extremamente difícil reparar de forma integral os danos oriundos da violação a direitos como a honra e a vida privada, uma vez que extrapolam o viés patrimonial e atingem a dignidade do indivíduo.

Diante disso, alguns doutrinadores, tendo por base o "Princípio do Menor Dano Possível", defendem de forma contundente o emprego da tutela preventiva/antecipatória para coibir os atos que violam direitos da personalidade na internet, através da retirada (prévia) das informações ou conteúdos (supostamente) ilícitos da "rede". ${ }^{71}$

Nesta linha de intelecto, Peck leciona que, pelo princípio do menor dano possível, é melhor que se retire do ar o conteúdo (ou a informação) divulgada na internet que esteja em pauta de discussão, do que mantê-lo na "rede", "mas, sendo infundada a denúncia, deve-se garantir a volta ao ar do conteúdo e também a punição daquele que tenha sido leviano, visto que aí a lesão será à liberdade, em vez de à privacidade (como vem ocorrendo mais comumente, em geral, ferindo a honra e a reputação)". ${ }^{72}$

\footnotetext{
${ }^{70}$ Disponível em: <http://www1.folha.uol.com.br/tec/2014/09/1522037-justica-determina-quebra-de-sigilo-dowhatsapp-apos-caso-de-montagens-pornos.shtml> Acesso em 16 de Out. de 2014.
}

${ }^{71}$ Alguns autores, inclusive, contrariando o art. 19 do Marco Civil da Internet "(Art. 19. Com o intuito de assegurar a liberdade de expressão e impedir a censura, o provedor de aplicações de internet somente poderá ser responsabilizado civilmente por danos decorrentes de conteúdo gerado por terceiros se, após ordem judicial específica, não tomar as providências para, no âmbito e nos limites técnicos do seu serviço e dentro do prazo assinalado, tornar indisponível o conteúdo apontado como infringente, ressalvadas as disposições legais em contrário.)", defendem, em relação à retirada de conteúdos supostamente ilícitos da internet, que violam direitos da personalidade, a aplicação do princípio do menor dano possível (em consonância com o princípio da proporcionalidade) no âmbito extrajudicial, através da ponderação, para responsabilizar os provedores de aplicações da internet que não fazem a exclusão de conteúdo quando são notificados extrajudicialmente ( "notice and take down"). Esse é o posicionamento de Marco Aurélio Florêncio Filho: "Certamente, ao editar o art. 19 da Lei 12.965/2014, o legislador minimizou a aplicação da regra do notice and take down, pois o provedor agora só será responsabilizado civilmente se após decisão judicial específica não retirar o conteúdo da Internet. Ora, se após notificação extrajudicial do usuário o provedor tinha condições de retirar as informações da Internet, quando verificado dano aos direitos do usuário, e não fez, será que não deveria ser responsabilizado pelo dano ocasionado? Diante do art. 19 da Lei 12.965/2014, a resposta provisória seria não. Parece-nos, entretanto, que diante do sopesamento de princípios, dignidade da pessoa humana, privacidade, de um lado; e, de outro, a liberdade de expressão, o provedor de aplicações de Internet após ser notificado pelo usuário e verificado o dano não poderá se afastar da responsabilidade de indenizar, sob a alegação de que não havia ordem judicial para retirar o conteúdo da Internet. Essa seria a interpretação constitucional que melhor se adequaria ao princípio da proporcionalidade.” FLORÊNCIO FILHO, Marco Aurélio. Apontamentos sobre a liberdade de expressão e a violação da privacidade no marco civil da internet. In: DEL MASSO, Fabiano; ABRUSIO, Julizana; FLORÊNCIO FILHO, Marco Aurélio (Coords.). Marco Civil da Internet: Lei 12. 965/2014. São Paulo: Revista dos Tribunais, 2014. p. 36. O autor consubstancia seu entendimento em precedente do STJ, apresentando o seguinte julgado: BRASIL. Superior Tribunal de Justiça. Recurso Especial $\mathrm{n}^{\circ}$ 1323754/RJ, rel. Min. Nancy Andrighi, j. 28.8.2012. 
O princípio do menor dano possível vem sendo adotado, in clusive, pela jurisprudência pátria, em relação às ações que tem por objetivo a retirada de nome de cadastro de inadimplentes. Eis trecho de decisão do Tribunal de Justiça de Minas Gerais:

Noutro norte, na ponderação dos possíveis prejuízos decorrentes da tutela de urgência para a proibição do apontamento do nome do consumidor aos cadastros de inadimplentes, é certo que a sua concessão, mesmo que ao final da instrução se julgue improcedente o pedido, é a medida que revela o menor dano possível. ${ }^{73}$

Este entendimento é totalmente condizente com a natureza dos direitos da personalidade e com a necessidade de proteção integral desses direitos, e pode (e deve) ser trazido e aplicado, analogamente, ao campo das biografias não autorizadas, até porque este tipo de obra literária pode ser publicado e disseminado na internet, contendo conteúdo ilícito.

É justamente devido à irreparabilidade dos direitos da personalidade que a seguinte regra, que se fundamenta, também, no princípio do menor dano possível, deve prevalecer: a liberdade de expressão deve ser limitada, prevalecendo os direitos da personalidade em sede de tutela preventiva.

Apesar de existirem leis específicas nas esferas criminal e civil no que tange à reparação e punição pela prática de ilícitos que atentam contra direitos da personalidade, a proteção efetiva destes tipos de direitos se dá, essencialmente, de forma plena, preventivamente, ou seja, através, também, da esfera processual, consoante já delineado de forma aprofundada em tópico específico (“A Tutela Inibitória”), a partir da inibição da prática do ilícito.

\subsection{A EFETIVA PROTEÇÃO: O ART. 12 DO Código CIVIL E A TUTELA INIBITÓRIA}

No início, houve objeção à teorização dos direitos da personalidade por parte de alguns autores, dentre eles, Savigny, que não admitia a existência de tais direitos por não conceber a hipótese do sujeito de direito ser, ao mesmo tempo, sujeito e objeto de seu próprio direito. Mas, conforme fora explicitado, sujeito e objeto, quanto aos direitos da personalidade, não se confundem. Os bens jurídicos protegidos pelos direitos da personalidade são os atributos ou projeções emanadas pelo ser humano, e não a personalidade em si. ${ }^{74}$ 
Assim, os direitos da personalidade, com o passar do tempo, se consolidaram, se fortaleceram e, na contemporaneidade, se perfazem verdadeiros "realizadores" da dignidade da pessoa humana, em decorrência da aproximação entre o direito público e o direito privado, que culminou na constitucionalização e repersonalização do direito civil.

Não foi à toa que, abandonadas as "tintas" patrimoniais do Código Civil de 1916, e sob a perspectiva da Constituição Federal de 1988, os direitos da personalidade, em onze artigos (11 a 21), foram inseridos na Parte Geral do Código Civil de 2002, com a inauguração de um capítulo dedicado à proteção da pessoa em seus aspectos essenciais. Isso representa o compromisso do direito civil com a promoção e a tutela da personalidade do ser humano. ${ }^{75}$

Segundo Leonardo Zanini, quando se passa os direitos da personalidade para o patamar de tutela constitucional da dignidade da pessoa humana, é preciso perceber que a proteção a esses direitos deve se dar de forma integrada, deixando-se de lado a divisão entre as esferas pública e privada do direito, estando situada, inclusive, acima desta dicotomia, tendo em vista que a dignidade é o valor fundamental do ordenamento jurídico pátrio. ${ }^{76}$

Corroborando com esta concepção, Gustavo Tepedino coloca que a tutela da pessoa humana, no atual contexto jurídico, superou a separação entre o direito público e o direito privado e, por isso, não se satisfaz apenas com as técnicas ressarcitórias de reparação de danos, sendo exigidos novos instrumentos que protejam a integridade do ser. ${ }^{77}$

É neste cenário de maior eficácia dos direitos da personalidade que se insere a possibilidade da adoção da tutela inibitória. Tais direitos foram incluídos, no texto constitucional, como direitos fundamentais que realizam a dignidade da pessoa humana, não podendo mais ser reduzidos à perspectiva patrimonial de outrora.

\footnotetext{
72 PINHEIRO, 2013, p. 421.

${ }^{73}$ BRASIL. Tribunal de Justiça de Minas Gerais. Agravo de Instrumento n ${ }^{\circ} 10694120042163001$, rel. Des. Otávio Portes, j. 24.4.2013. Disponível em: <http://tj-mg.jusbrasil.com.br/jurisprudencia/115406249/agravo-deinstrumento-cv-ai-10694120042163001-mg>. Acesso em: 17 out. 2014.

${ }^{74}$ BORGES, 2007, p. 20. Além de Savigny, destacam-se outros autores alemães, como Von Thur e Enneccerus, que ficaram conhecidos por "negarem" (por suas "teorias negativistas") os direitos da personalidade. In: SZANIAWSKI, 1993, p. 37.

${ }^{75}$ SCHREIBER, 2014, p. 12.
} 
A violação aos direitos da personalidade representa, primordialmente, ofensa à esfera moral do indivíduo. Desse modo, o dano moral consiste justamente na lesão a um atributo da pessoa, estando configurados, pois, danos de ordem extrapatrimonial, quando houver lesão a qualquer um dos direitos da personalidade ${ }^{78}$, que, pela própria natureza, não podem ser reparados em sua integralidade, mas, somente, compensados. ${ }^{79}$

Portanto, torna-se pertinente, e até necessária, não apenas a tutela repressiva, indenizatória, mas a busca de outros meios que garantam a proteção integral dos direitos da personalidade, notadamente de forma preventiva ${ }^{80}$, consoante prevê o art. 12 do CC/2002.

No segundo tópico da análise até aqui delineada (“As Normas de Direitos Fundamentais") constatou-se que na colisão entre direitos fundamentais é preciso sopesar os princípios envolvidos no caso concreto para que o magistrado profira uma decisão adequada à proteção dos direitos envolvidos, uma vez que não existem direitos absolutos.

Dessa forma, é possível aferir que a liberdade de expressão e os direitos de acesso à cultura e à informação podem (e devem) ser limitados ao colidirem com direitos da personalidade em determinadas situações. E isto deve ocorrer não somente em sede de reparação, mas, também, em sede de prevenção.

Neste sentido, retoma-se a pergunta já elencada no tópico supramencionado: "tendo conhecimento da iminente violação à proteção de sua personalidade, seria possível que o indivíduo recorresse à justiça através da tutela inibitória a fim de cessar esta ameaça?”

Pois bem. O art. 12 do Código Civil dispõe:

Art. 12. Pode-se exigir que cesse a ameaça, ou a lesão, a direito da personalidade, e reclamar perdas e danos, sem prejuízo de outras sanções previstas em lei.

\footnotetext{
76 ZANINI, 2011, p. 140.

77 TEPEDINO, 2004, p. 23-24.

78 SCHREIBER, 2014, p. 16.

${ }^{79}$ GAGLIANO; PAMPLONA FILHO, 2011, p. 92. Os autores se reportam, ainda, aos ensinamentos de Orlando Gomes de que o dano moral não é indenizável, pois a indenização significa o fim do prejuízo e das consequências, o que não ocorre quando se trata de ofensa à esfera extrapatrimonial, sendo o dano a esta, portanto, "compensável".
}

${ }^{80}$ Além das obrigações de fazer e não fazer posteriores à lesão. 
Parágrafo único. Em se tratando de morto, terá legitimação para requerer a medida prevista neste artigo o cônjuge sobrevivente, ou qualquer parente em linha reta, ou colateral até o quarto grau.

Assim, dá interpretação direta deste dispositivo, cumulado com o inciso XXXV do art. $5^{\circ}$ da Constituição da República, juntamente com toda teoria jurídica já abordada sobre a Tutela Inibitória, é possível responder que sim, inclusive através de liminar, desde que, na análise do caso concreto destrinchado na ação (inibitória), o juiz realize o sopesamento entre os direitos fundamentais envolvidos, levando em consideração todas as circunstâncias que rodeiam os fatos, especialmente a extensão dos danos que poderão ser causados na prática do ato supostamente ilícito, a (im)possibilidade de efetiva reparação, além do corpo probatório apresentado em relação à ameaça e a possibilidade (leia-se probabilidade) de dano.

E mesmo que o direito da personalidade já tenha sido violado, a tutela inibitória pode ser utilizada para cessar a repetição ou a continuidade da prática do ato ilícito.

Se posicionando a favor da constatação apontada e ao que instituem os referidos dispositivos mencionados, Guilherme Linhares aduz que "se alguém tem um direito da personalidade [a ser] violado deve, sim, fazer uso desse instrumento de tutela preventiva, único, aliás, que garante a efetiva e adequada tutela dos chamados novos direitos". ${ }^{81}$

Nesta linha de intelecção, Elisabete Amaro sustenta que a "tutela dos direitos da personalidade deve ser integral, garantindo a sua proteção em qualquer situação. $\mathrm{O}$ art. 12 do CC responde a esta necessidade de ampliação da tutela como o mecanismo da tutela inibitória”. 82

O próprio Marinoni atesta que o art. 461 do CPC, uma vez interpretado “à luz da teoria da tutela inibitória abre oportunidade para procedimentos capazes de tutelar de forma adequada e efetiva os direitos, notadamente, os de conteúdo não patrimonial". ${ }^{83}$

E Cristiano Chaves ensina que "a tutela (proteção) jurídica dos direitos da personalidade, em sede civil (sem prejuízo da tutela penal), se consubstanciará por meio de medidas repressivas [...] e, por igual, de medidas preventivas - a chamada tutela específica". ${ }^{84}$

Isso é o que preceitua o Enunciado 140 da III Jornada de Direito Civil do CJF: “A primeira parte do art. 12 do Código Civil refere-se às técnicas de tutela específica, aplicáveis de ofício, enunciadas no art. 461 do Código de Processo Civil, devendo ser interpretada com 
resultado extensivo". E, neste mesmo sentido, o Enunciado 5 da I Jornada de Direito Civil do CJF dispôs que "As disposições do art. 12 têm caráter geral e aplicam-se, inclusive, às situações previstas no art. 20".

É dessa forma, pois, que Roxana Borges prevê a tutela preventiva do direito à imagem: "a pessoa ofendida pode requerer judicialmente a interrupção da exposição de sua imagem e a destruição dos meios físicos utilizados para tanto, além de, se possível, obter a tutela inibitória preventiva". ${ }^{85}$

E é assim que Beltrão salienta a possibilidade de o juiz adotar todas as providências "para impedir ou fazer cessar atos que violem a vida privada da pessoa natural. O Novo Código Civil atribui ao juiz autonomia para, diante do poder geral de cautela, determinar a medida mais adequada no sentido de impedir a violação ao direito da personalidade". ${ }^{86}$

Ademais, cumpre alumiar que a tutela preventiva não é censura, como os arautos das liberdades de informação, de imprensa e de expressão "pregam". Como apontou a civilista Silmara Chinellato em sua apresentação na audiência pública do STF para consubstanciar a ADI n ${ }^{\circ} 4.815 / \mathrm{DF}$, os direitos de liberdade não são ilimitados e devem ser ponderados à luz de outros direitos de mesma hierarquia.

Godoy exemplifica: "Não faria sentido algum, por exemplo, permitir publicação ou programa que, frise-se, de antemão, já se saiba falso ou sensacionalista, em nome da preservação de um direito que não é absoluto e que, se indevidamente exercido, causará danos irreparáveis". ${ }^{87}$ E na tradução deste autor, Jean Carbonnier amestra:

\footnotetext{
${ }^{81}$ SILVA, Guilherme Linhares Valério da. Breves apontamentos acerca dos direitos da personalidade e novas formas de tutela jurisdicional. In: BUENO, Cassio Scarpinella (Coord.). Impactos Processuais do Direito Civil. Salvador: Saraiva, 2008. p. 74.

${ }^{82}$ AMARO, Elisabete Aloia. Responsabilidade civil por ofensa aos direitos da personalidade. In: NERY, Rosa Maria de Andrade; DONNINI, Rogério (Coords.). Responsabilidade Civil - Estudos em homenagem ao professor Rui Geraldo Camargo Viana. São Paulo: Revista dos Tribunais, 2009. p. 166.

${ }^{83}$ MARINONI, 2004, p. 306.

${ }^{84}$ FARIAS, 2004, p. 134, grifos do autor. O autor lembra que a tutela específica "pode ser individual ou coletiva, reguladas, respectivamente, pelos arts. 461 do Código de Processo Civil e 84 do Código de Defesa do Consumidor". Ibid.
} 
[...] as condenações pecuniárias sob a forma de perdas e danos são pouco eficazes. Melhor que esperá-las é a reparação in natura, e sobretudo uma ação preventiva destinada a ser mais rápida que as indiscrições, por meio de medidas tais que apreendam ou sequestrem jornais, livros, filmes etc. que portem atentado à vida privada. ${ }^{88}$

Portanto, em regra, é possível (e necessária), sim, a utilização da tutela inibitória no âmbito de proteção (integral) dos direitos da personalidade. Não se trata de censura (prévia ou privada), e sim de proteção de direito fundamental respaldada pela Constituição, pela lei civil e pelos princípios da dignidade da pessoa humana e do menor dano possível.

Qualquer indivíduo que tiver conhecimento sobre divulgação (ou possível divulgação) de imagens que violam (ou violarão) sua honra e sua intimidade na Internet, por exemplo, poderá requerer em juízo que a ameaça ou o ilícito seja imediatamente suspenso, tutela que deverá ser concedida caso estejam consubstanciados os requisitos (já expostos) e seja feito o sopesamento em relação a outros direitos fundamentais que circundam o caso.

Verifica-se, portanto, que a tutela inibitória é instrumento extremamente adequado e eficaz à proteção dos direitos da personalidade. Então, sem dúvida, a Tutela Inibitória pode ser utilizada, na contemporaneidade, como meio de proteção (integral) dos direitos da personalidade.

\section{CONCULSÃO}

Em tópico inaugural, após a introdução, foi possível verificar os aspectos conceituais e estruturais dos direitos fundamentais (regras e princípios), e as restrições quando

\footnotetext{
${ }^{85}$ BORGES, 2007, p. 158.

${ }^{86}$ BELTRÃO, 2014, p. 203.

${ }^{87}$ GODOY, 2001, p. 112. E complementa, o autor, o entendimento: "Sim, porque, como se sabe, o dano moral é daqueles que não comportam reparação ou restituição integral, retorno completo à situação anterior”.

88 CARBONNIER, Jean apud GODOY, 2001, p. 112. E na obra do autor francês citada por Godoy: "lês condamnations pécuniaires sous forme de dommages-intérêts sont peu efficaces. Il y a mieux à espérer d'une réparation en nature, et surtout d'une action préventive destinée à gagner de vitesse lês indiscréations, par dês mesures telles que saisies ou séquestres dês journaux, livres, films, etc, portant atteinte à la vie privée". CARBONNIER, Jean. Droit civil: lês personnes. Paris: Presses Universitaires de France, 1992. p. 129.
} 
há colisão com outros direitos de mesma espécie. Em seguida, foram destrinchados os direitos da personalidade, a liberdade de expressão e os direitos de acesso à cultura e à informação, sendo exposto os nuances que lhes rodeiam.

Em seguida, como foco de estudo deste trabalho, foi analisado de forma aprofundada o instituto da Tutela Inibitória através do Código de Processo Civil (e o NCPC) e da doutrina especializada, sendo apresentados, em tópico específico, casos concretos que envolveram o de certa forma o estudo proposto. Foi analisada, ainda, a partir do contexto contemporâneo e do advento da Internet, a possibilidade de tutela jurisdicional preventiva dos direitos da personalidade no ordenamento jurídico brasileiro.

Por fim, foi constado que é possível, na atual conjuntura jurídica e social do país, a partir do sopesamento entre direitos fundamentais, a utilização da tutela inibitória como instrumento de proteção dos direitos da personalidade, inclusive de modo preventivo, tendo por base a probabilidade de ocorrência, continuidade ou repetição de evento danoso (ameaça ou lesão à direito) e a dificuldade de efetiva reparação.

\section{REFERÊNCIAS}

ALEXY, Robert. Teoria dos direitos fundamentais. Tradução de Virgílio Afonso da Silva. $2^{\mathrm{a}}$ ed. São Paulo: Malheiros, 2011.

AMARO, Elisabete Aloia. Responsabilidade civil por ofensa aos direitos da personalidade. In: Responsabilidade Civil - Estudos em homenagem ao professor Rui Geraldo Camargo Viana. Rosa Maria de Andrade Nery e Rogério Donnini, coordenação. São Paulo: Revista dos Tribunais, 2009.

ÁVILA, Humberto. Teoria dos Princípios: da definição à aplicação dos princípios jurídicos. 14. ed. São Paulo: Malheiros, 2013.

BARROSO, Luís Roberto. Liberdade de expressão versus Direitos da Personalidade. Colisão de Direitos Fundamentais e Critérios de Ponderação. In: Leituras Complementares de Direito Civil: o direito civil-constitucional em concreto. Cristiano Chaves de Faria, organizador. Salvador: JusPODIVM, 2007. 
BINICHESKI, Paulo Roberto. Responsabilidade Civil dos Provedores de Internet. Curitiba: Juruá, 2011.

BORGES, Roxana Cardoso Brasileiro. Direitos de Personalidade e Autonomia Privada. 2. ed. São Paulo: Saraiva, 2007.

CASTRO, Mônica N. A. da S. Honra, imagem, vida privada e intimidade, em colisão com outros direitos. Rio de Janeiro: Renovar, 2002.

LEONARDI, Marcel. Internet: Elementos Fundamentais. In: Responsabilidade Civil na Internet e nos demais Meios de Comunicação. Manoel J. Pereira dos Santos e Regina Beatriz Tavares da Silva, coordenadores. São Paulo: Saraiva, 2007.

LORENZETTI, Ricardo Luis. La tutela civil inhibitoria. Buenos Ayres: La Ley, 1995.

MARINONI, Luiz Guilherme e ARENHART, Sérgio Cruz. Curso de Processo Civil. Vol. 4. São Paulo: Revista dos Tribunais, 2008. . Técnica processual e tutela dos direitos. São Paulo: Revista dos Tribunais, 2004. . Tutela Inibitória individual e coletiva. $4^{\mathrm{a}}$ ed. São Paulo: Revista dos Tribunais,

2006.

PAESANI, Liliana Minardi. Direito e Internet. 6a ed. São Paulo: Atlas, 2013.

PINHEIRO, Patrícia Peck. Direito Digital. 4ª ed. São Paulo: Saraiva, 2013.

SILVA, Guilherme Linhares Valério da. Breves apontamentos acerca dos direitos da personalidade e novas formas de tutela jurisdicional. In: Impactos Processuais do Direito Civil. Cassio Scarpinella Bueno, coordenador. São Paulo: Saraiva, 2008.

SILVA, José Afonso da. Curso de Direito Constitucional Positivo. $30^{\mathrm{a}}$ ed. São Paulo: Malheiros Editores, 2008.

SILVA, Virgílio Afonso da. A Constitucionalização do Direito: Os direitos fundamentais nas relações entre particulares. $1^{\text {a }}$ Ed. São Paulo: Malheiros, 2005. 
. O conteúdo essencial dos direitos fundamentais e a eficácia das normas constitucionais. Revista de Direito do Estado. n. 4. São Paulo: Renovar, 2006.

SPADONI, Joaquim Felipe. Ação Inibitória: a ação preventiva prevista no art. 461 do CPC. São Paulo: Revista dos Tribunais, 2002. 